\title{
Article \\ Solution of Bullet Proof Wooden Frame Construction Panel with a Built-In Air Duct
}

\author{
Anatolijs Borodinecs* $*$, Aleksandrs Geikins, Elina Barone, Vladislavs Jacnevs and Aleksejs Prozuments \\ Department of Heat Engineering and Technology, Riga Technical University, Kipsalas Street 6, \\ LV-1048 Riga, Latvia; aleksandrs.geikins@rtu.lv (A.G.); elina.barone@rtu.lv (E.B.); \\ Vladislavs.Jacnevs@edu.rtu.lv (V.J.); aleksejs.prozuments@rtu.lv (A.P.) \\ * Correspondence: anatolijs.borodinecs@rtu.lv
}

check for updates

Citation: Borodinecs, A.; Geikins, A.; Barone, E.; Jacnevs, V.; Prozuments, A. Solution of Bullet Proof Wooden Frame Construction Panel with a Built-In Air Duct. Buildings 2022, 12, 30. https://doi.org/10.3390/ buildings 12010030

Academic Editor: Shi-Jie Cao

Received: 18 November 2021

Accepted: 27 December 2021

Published: 31 December 2021

Publisher's Note: MDPI stays neutral with regard to jurisdictional claims in published maps and institutional affiliations.

Copyright: (C) 2021 by the authors. Licensee MDPI, Basel, Switzerland. This article is an open access article distributed under the terms and conditions of the Creative Commons Attribution (CC BY) license (https:// creativecommons.org/licenses/by/ $4.0 /)$.

\begin{abstract}
The growing terrorism threats across the world play an important role in the design of civil buildings and living areas. The safety of personnel is a top priority in unclassified buildings, especially military buildings. However indoor air quality and thermal comfort has a direct impact on personal productivity and ability to concentrate on duties and affect the decision making in stress conditions. The use of wooden structures is becoming more common in the building construction, and application of wooden frame structures for the construction of new buildings as well as for retrofitting the existing buildings. Prefabricated wooded frame construction perfectly fits need of unclassified buildings, allowing significant reduction of construction time and integration of various active and passive elements, such as a fresh air supply duct. Within the scope of this paper a $12 \mathrm{~mm}$ thick ballistic panel made of aramid was tested. Ballistic panel, thermal conductivity, and fire resistance of wooded construction panel with embedded air duct were analyzed for the various modelled exterior wall solutions. The main advantage of the proposed technology is fast and qualitative modular construction of unclassified buildings, providing all modern requirements not only for safety, but also for the energy efficiency and indoor air quality. It was found that bullet proof aramid panels do not reduce overall fire safety in comparison to traditional construction materials. However embedded outdoor air supply ducts significantly reduces construction heat transfer coefficient.
\end{abstract}

Keywords: wood construction; air duct; ballistic proof; U-value; fire tests

\section{Introduction}

The safety of personnel is a top priority in unclassified buildings, especially military buildings. However indoor air quality and thermal comfort has a direct impact on personal productivity and ability to concentrate on duties and affect the decision making in stress conditions. European legislation is forcing buildings and industry to switch energy systems to efficient, decarbonize and renewable based [1]. In order to maintain a healthy and comfortable environment for the occupants of the building, it is important to maintain a good indoor environment with highly efficient building envelopes and energy systems [2]. Pervious study has shown $[3,4]$ that proper approach to retrofitting of all types of buildings allows sustainable development of whole energy supply grid.

There are numerous materials which ensure bullet proof properties: bimodal nanostructured metals [5], polymer-matrix composites (high-density polyethylene and polypropylene reinforced with aramid fabric) [6], para-aramid 3D angle-interlock fabrics [7] etc. One of the innovative solutions is to use bio composite armors made of high-density polyethylene (HDPE) reinforced with chonta palm wood micro-particles [8] or lightweight ballistic materials which are relatively new [9], or to use cross-laminated timber (CLT) $[10,11]$ as ballistic construction material. The penetration depths of the projectiles are related to physical properties of the wood [12,13], also in cold climates [14]. Aramid based ballistic panels were investigated in this study to ensure bullet protection and material integrity. The bullet action depends on the various layers of the aramid fiber materials [15-17]. 
This study focuses development on whole ballistic proof wall concept development which insures better heat transferee coefficient, integration of ventilation systems, and fire resistance. As bullet proof materials the aramid fiber composite material was chosen. These materials can resist flame but $300{ }^{\circ} \mathrm{C}$ may cause chemical decomposition of aramid fiber $[18,19]$. The paper also shows the integrated duct's impact of $U$ value in wooden panel. The thermal conductivity of the wall studs and attenuation is an important factor affecting the thermal performance of the wall [20].

Sustainable [21,22] ballistic panel, thermal conductivity, and fire resistance of wooded construction panel with embedded air duct were analyzed for the various modelled exterior wall solutions. The main advantage of the proposed technology is fast and qualitative modular construction of unclassified buildings [23,24], providing all modern requirements not only for safety, but also for the energy efficiency and indoor air quality. Installation of ventilation systems also is a vitally import to ensure overall system suitability. Emission source control and ventilation are the two major ways to improve indoor air quality [25]. As well as proposed wall solution are unified prefabricated construction elements that significantly reduce construction time and reduce errors during the construction of buildings. Modular construction is one of the most efficient off-site construction methods [26,27]. The presented cases reflect the retrofitting solutions of existing external building envelope. To facilitate the construction process of a new building the wooden frame structures are considered in the scope of this research. Such structures allow precise control of materials and high assembly quality at factory during production. Also wooded frame construction can ensure erection of fast and comfortable temporary shelter development in comparison to mobile traditional tents [28,29].

\section{Materials and Methods}

Application of wooded frame construction for the construction of new buildings as well as retrofitting the existing buildings allow for significant reduction of construction time and to ensure assurance of construction works. The design of wooden frame construction can be automated, thus, minimizing not only construction time but also the design process.

To develop the most optimal solution of wooded frame wall reinforced with ballistic panels, six different wall assemblies were proposed and tested in a climatic chamber (see Table 1). Several solutions were combined in one test wall. Ballistic panel can be classified as external or internal placement. Both types have equal bullet proof protection properties.

Table 1. Description of samples.

\begin{tabular}{cccc}
\hline & Sample D & Sample F & Sample G \\
\hline Internal finishing: & $\begin{array}{c}\text { Smart water } \\
\text { vapor retarder }\end{array}$ & $\begin{array}{c}\text { Smart water } \\
\text { vapor retarder }\end{array}$ & $\begin{array}{c}\text { Smart water } \\
\text { vapor retarder }\end{array}$ \\
\hline Thermal insulation & Mineral wool & Extruded Polystyrene & Extruded Polystyrene \\
\hline External finishing & Ballistic panels & Ballistic panels & Wind barriers \\
\hline $\begin{array}{c}\text { Embedded } \\
\text { ventilation duct }\end{array}$ & n/a & n/a & n/a \\
\hline Internal finishing: & Water vapor retarder & Water vapor retarder & Water vapor retarder \\
\hline Thermal insulation & Mineral wool & Extruded Polystyrene & Extruded Polystyrene \\
\hline $\begin{array}{c}\text { External finishing } \\
\text { Embedded } \\
\text { ventilation duct }\end{array}$ & Ballistic panels & Ballistic panels & Wind barriers \\
\hline
\end{tabular}

Separate single prototypes were built to test connectors and construction specifics.

In addition, separate demo walls with build-in ducts were produced (see Figure 1). This allowed to test the overall efficiency of wall assembly and to evaluate integration of 
addition ballistic protection. The different ventilation ducts were taken into consideration. The main aim was to create a layout that prevents from bullet penetration.

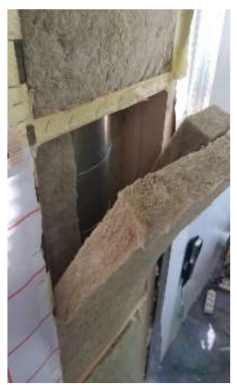

(a)

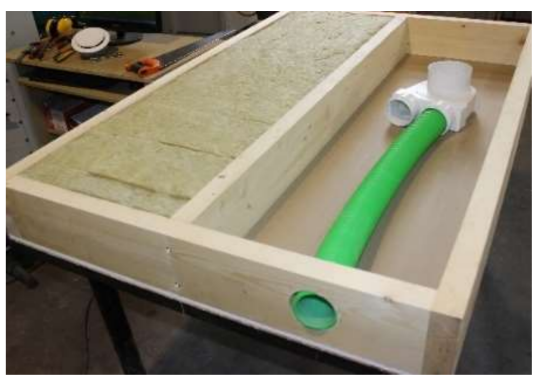

(b)

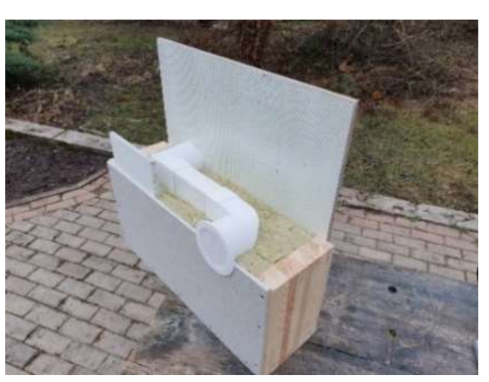

(c)
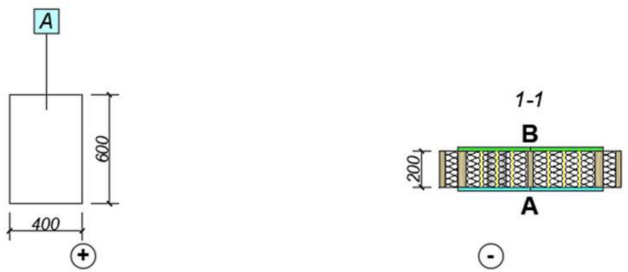

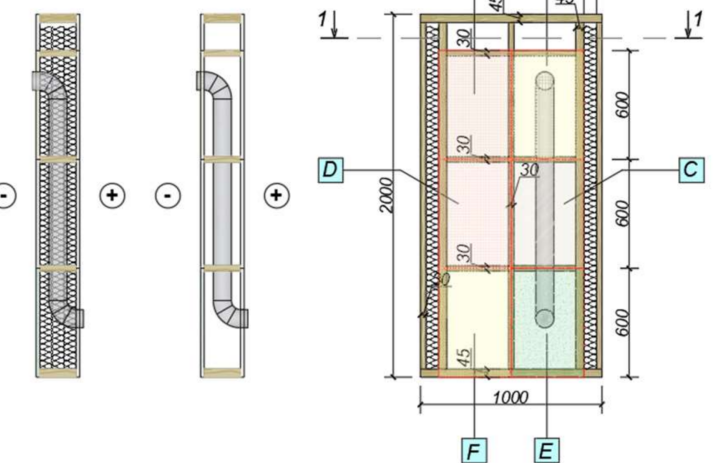

A $\odot$

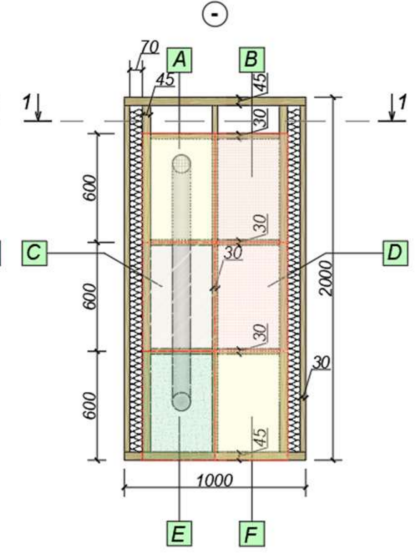

B

(d)

Figure 1. Wooded frame test construction. (a) steel duct; (b) flexible plastic duct; (c) plastic ducts; (d) test wall dimensions.

The research methodology includes three main activities: heat transfer calculations, testing of fire resistance of aramid panels and fire testing of whole wall system.

Hydrothermal performance of the external wooded frame wall structure reinforced with ballistic panels were already previously published [29]. It was found that external ballistic panels block water vapor flow which can cause interstitial condensation in cold climates. According to the performed study, the risk of interstitial condensation can be minimized by application of smart water vapor retarder.

\subsection{Proposed Ventilation System}

To minimize construction or retrofitting time, one of possible solution is to use integrated ventilation systems. Integrated ventilation systems could be local (room/floor scale) and centralized (building scale). However, integrated ventilations systems in the building structure compromises the ballistic protection of the same structure. Therefore, in scope of this paper extra ballistic protection was proposed. One of alternative solutions is integration of plastic ducts for installation of room-based ventilation. Plastic ducts have lower negative impact on thermal performance; $12 \mathrm{~mm}$ thick aramid based ballistic panels were investigated in this study to ensure bullet protection and material integrity (see Figure 2). 


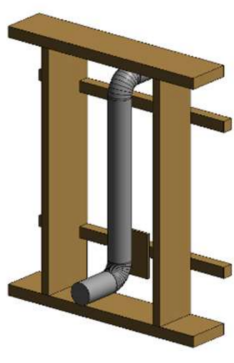

(a)

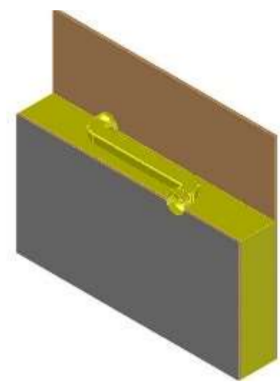

(b)

Figure 2. 3D visualization of proposed concept. (a) Aramid backboard panel for extra ballistic protection; (b) External balistic panel.

\subsection{Heat Loss Calculations}

In scope of this study the overall thermal performance was analyzed in THERM and COMSOL physic software. Both softwares perform calculation in compliance with ISO 10211:2007: Thermal bridges in building construction-Heat flows and surface temperatures-Detailed calculations [30]. Evaluation of thermal performance includes practical measurement of thermal conductivity and water vapor permeance. These are the two main parameters which should be considering in order to evaluation thermal performance of wall assembly as well as risk of interstitial condensation. Long term interstitial condensation without sufficient drying in summertime can negatively affect overall performance of whole structure and to have negative effect on materials properties. Lambda Series heat flow meter were done. The system is ideally suited for the measurement of insulating materials with thermal conductivities up to $1.0 \mathrm{~W} /(\mathrm{m} \cdot \mathrm{K})$ and materials with smaller thicknesses. The system works according to ASTM C 518 [31], ISO 8301 [32], DIN EN 12667 [33], DIN EN 13163 [34], and JIS A 1412 [35]. So-called thermal coupling factor (L2D) in turn is calculated using this formula [36]:

$$
L_{2 D}=\frac{\Phi_{1 j}}{\Theta_{i}-\Theta_{e}},
$$

where $L_{2 D}$-is a numerically defined two-dimensional (2D) technical thermal coupling factor considered for the joints of a building, $\mathrm{W} /(\mathrm{m} \cdot \mathrm{K})$;

$\Phi_{1 j}$-is the heat flow rate of the linear bridge, $\mathrm{W} / \mathrm{m}$;

$\Theta_{i}$-is the internal temperature, $\mathrm{K}$;

$\Theta_{e}$-is the external temperature, $\mathrm{K}$.

\subsection{Fire Resistance Tests}

Fire resistance was tested in special laboratory located at Forest and Wood Products Research and Development Institute. The fire resistance tests were conducted in accordance with EN 13501-1: Fire classification of construction products and building elements [37].

\section{Results}

\subsection{Airtightness Ensuring of Proposed Construction}

In order to ensure airtightness in case of emergency (smoke, fire), the air supply valve should provide sufficient airtightness, which is to be achieved instantly after the emergency event is identified. The possible solution is presented in Figure 3. 

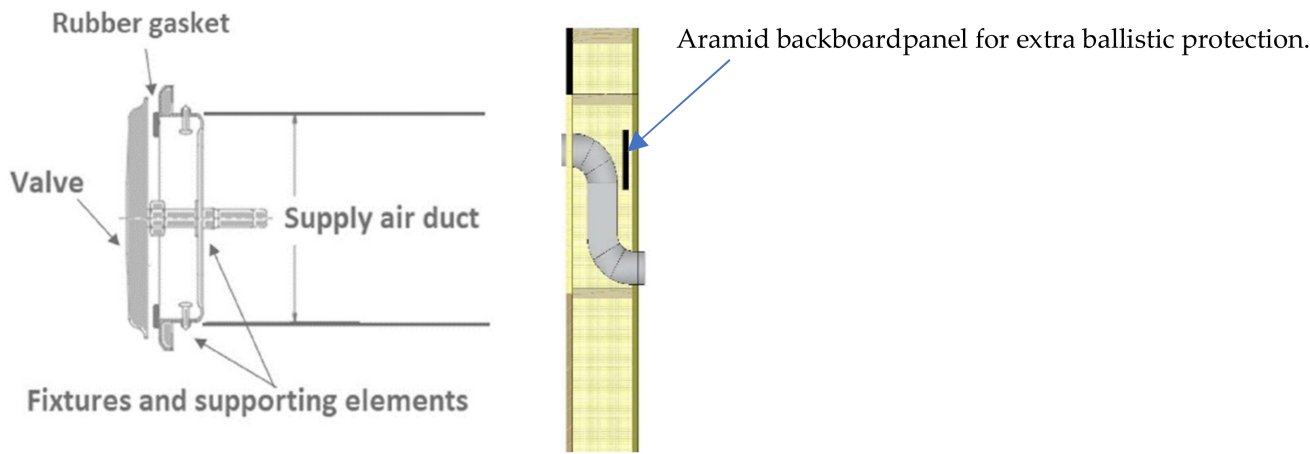

Figure 3. Possible solutions for built-in ventilation systems with additional ballistic protection and smoke leakage.

The valve is installed directly into the duct outlet by using fasteners and supporting elements. The valve housing is equipped with rubber gasket that provides maximum air tightness. The rubber gasket is fire and acid resistant. It consists of silicon and fluor-rubber composite that complies with stringent resistance standards and has a high durability against temperature and open flame. The airtight supply valve (as a whole unit) has a fire resistance class of EI 15 which will increase as the product development progresses. The wall structure in which the air valve is mounted must meet a minimum fire resistance class of EI 60 (see Table 2).

Table 2. Overview of the airtight supply valve characteristics.

\begin{tabular}{|c|c|c|c|c|c|c|c|}
\hline \multicolumn{2}{|c|}{ General Characteristics } & \multicolumn{3}{|c|}{ Materials } & \multicolumn{3}{|c|}{ Technical Compliance } \\
\hline Function & Application & $\begin{array}{l}\text { Housing } \\
\text { material }\end{array}$ & $\begin{array}{l}\text { Sealant } \\
\text { material }\end{array}$ & $\begin{array}{l}\text { Fasteners } \\
\text { and screws }\end{array}$ & $\begin{array}{l}\text { Air tightness } \\
\text { class }\end{array}$ & $\begin{array}{c}\text { Fire } \\
\text { resistance }\end{array}$ & $\begin{array}{c}\text { Fire } \\
\text { resistance } \\
\text { class } 1 \text { for } \\
\text { wall }\end{array}$ \\
\hline $\begin{array}{l}\text { Outdoor air } \\
\text { supply in } \\
\text { natural } \\
\text { ventilation } \\
\text { systems }\end{array}$ & $\begin{array}{l}\text { Military: } \\
\text { temporary } \\
\text { and portable } \\
\text { structures }\end{array}$ & $\begin{array}{c}\text { Coated } \\
\text { galvanized } \\
\text { sheet metal }\end{array}$ & $\begin{array}{l}\text { Neoprene- } \\
\text { composed } \\
\text { elastomer }\end{array}$ & $\begin{array}{c}\text { Aluminum, } \\
\text { iron }\end{array}$ & $\begin{array}{l}\text { Class 4, EN } \\
1751: 2014\end{array}$ & EI 15 & EI 60 \\
\hline
\end{tabular}

\subsection{Performance of Wood Frame Construction with Integrated Ventilation Ducts $U$-Value}

Results of aramid panel' thermal conductivity measurements in HFM 446 Lambda Series heat flow meter have shown (Figure 4) similar data lambda $\lambda_{10}=0.30 \mathrm{~W} /(\mathrm{m} \cdot \mathrm{K}$ ) in this case measurements were done at temperature above $+10^{\circ} \mathrm{C}$ and extrapolated to reference temperature $+10^{\circ} \mathrm{C}$.

As it can be seen from above mentioned table it is recommended to place air duct close to internal surface. Thus, minimizing water vapor condensation risk on metal surface of air duct.

For all three cases the U-value for wooden frame construction is $0.27 \mathrm{~W} /\left(\mathrm{m}^{2} \cdot \mathrm{K}\right)$. Without the integrated ducts U-value drops to $0.26 \mathrm{~W} /\left(\mathrm{m}^{2} \cdot \mathrm{K}\right)$. U-value strictly depends on thermal conductivity of main thermal insulation layer, and in presented cases the thermal conductivity was assumed $0.042 \mathrm{~W} /(\mathrm{m} \cdot \mathrm{K})$. By replacing materials with thermal conductivity of $0.034 \mathrm{~W} /(\mathrm{m} \cdot \mathrm{K})$ the $\mathrm{U}$-value can be reduced to $0.22 \mathrm{~W} /\left(\mathrm{m}^{2} \cdot \mathrm{K}\right)$. This value could be satisfactory for the construction of temporary buildings. More accurate data could be calculated based on predicted exploitation time of temporary building and design indoor air parameters. 


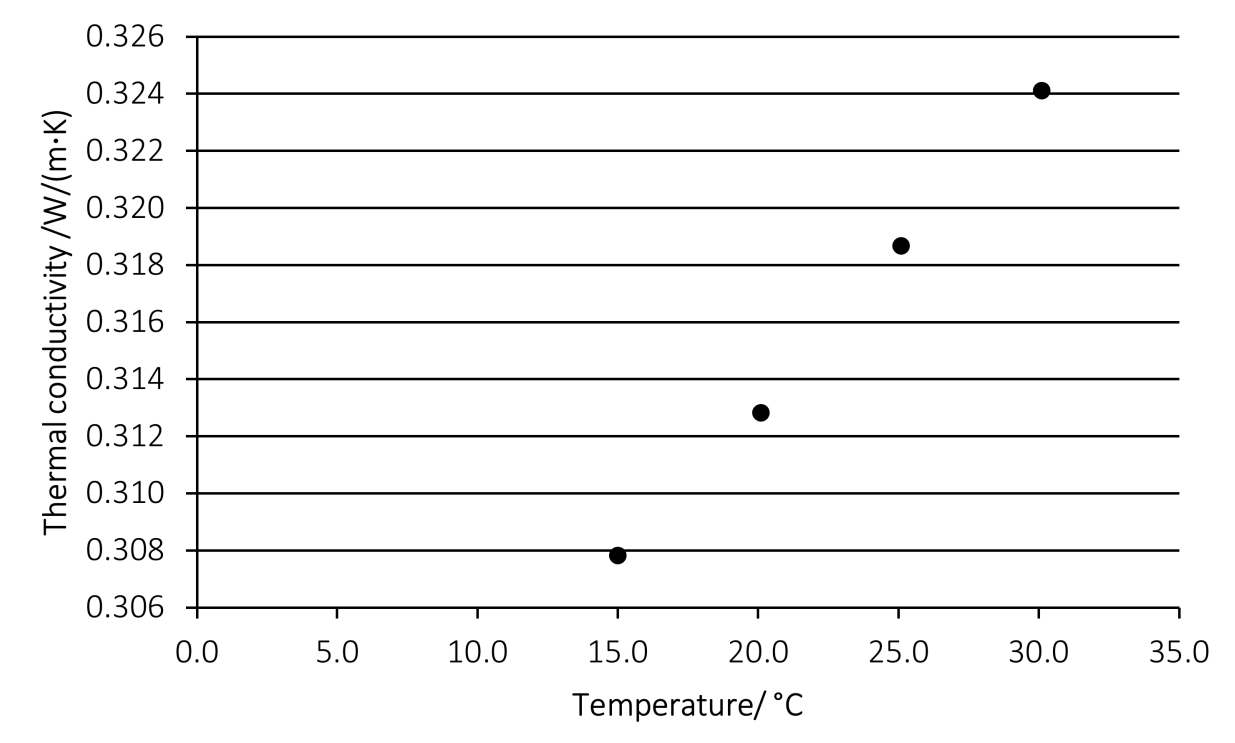

Figure 4. Thermal conductivity dependence on ambient temperature.

In addition to thermal conductivity, specific heat was measured (Figure 5). Specific heat capacity Cp10 is $860 \mathrm{~K} / \mathrm{kg} / \mathrm{K}$.

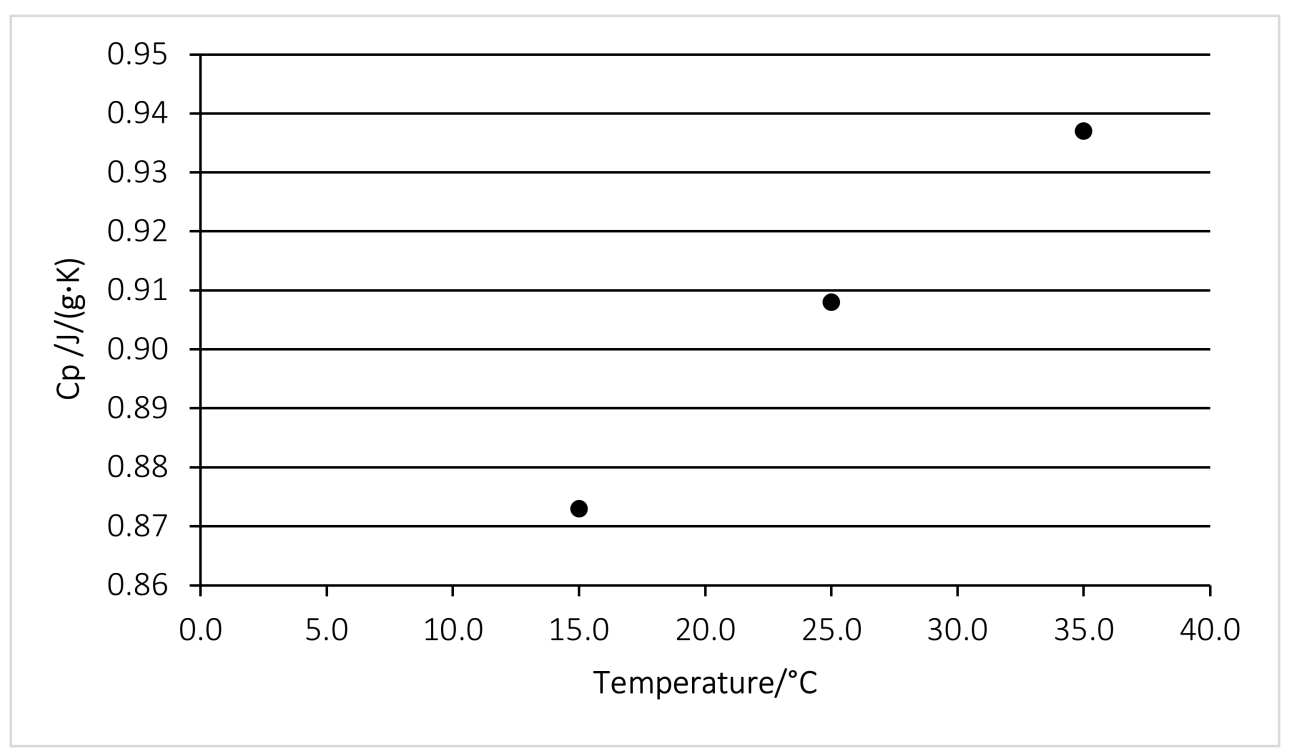

Figure 5. Specific heat measurements.

It should be taken into consideration that in case of lightweight structures the embedded ducts can have negative impact in comparison to retrofitting the existing heavy weight constructions. Analysis of three cases is shown in Table 3. Indoor and outdoor temperatures for the calculation model were set as follows: indoor $\left(+20^{\circ} \mathrm{C}\right)$ and outdoor $\left(-10^{\circ} \mathrm{C}\right)$. 
Table 3. Effect of integrated duct on light weight construction performance.

\begin{tabular}{l|cr}
\hline Participial Scheme & Temperature Distribution & $\begin{array}{c}\text { Surface Temperature on Internal } \\
\text { Surface behind Duct }\end{array}$ \\
\hline & & \\
\hline
\end{tabular}

There is no negative impact on the external building elements' heat transmittance when the warm exhaust air circulates through the embedded ducts. However, if the mechanic ventilation is switched off, it causes the increase of heat transmittance coefficient. The comparison of the heat flow in wooden frame construction (used as extra thermal insulation of existing structure) with integrated ducts, without forced airflows is shown in Figure 6. Duct air is assumed as steady air.
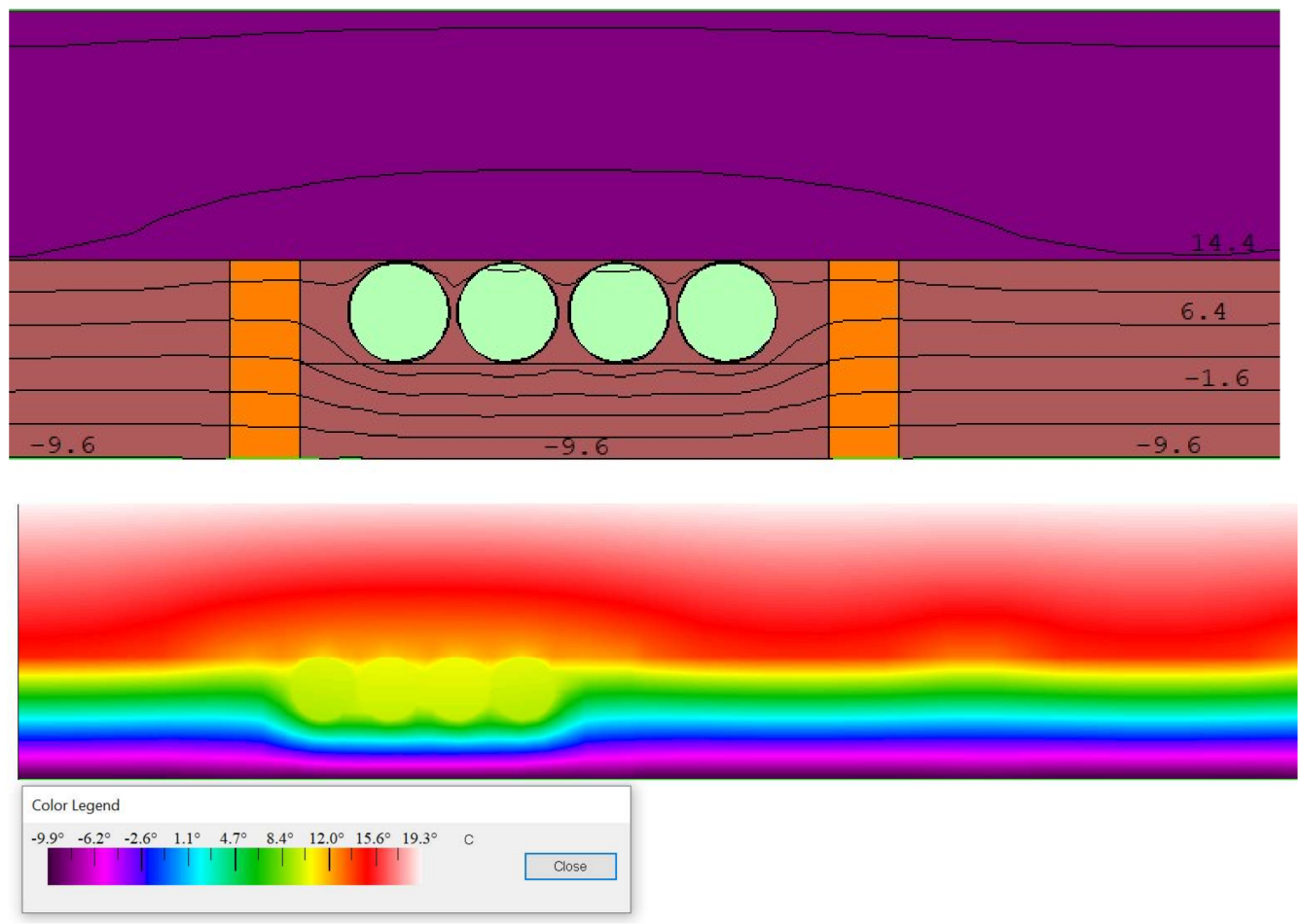

Figure 6. Temperature distribution and heat flow in wooden frame construction.

As it can be seen the integrated duct slightly decreases the overall performance of the whole construction, while ventilation systems are not in use. Figure 7 presents the impact of integrating plastic pipe. 

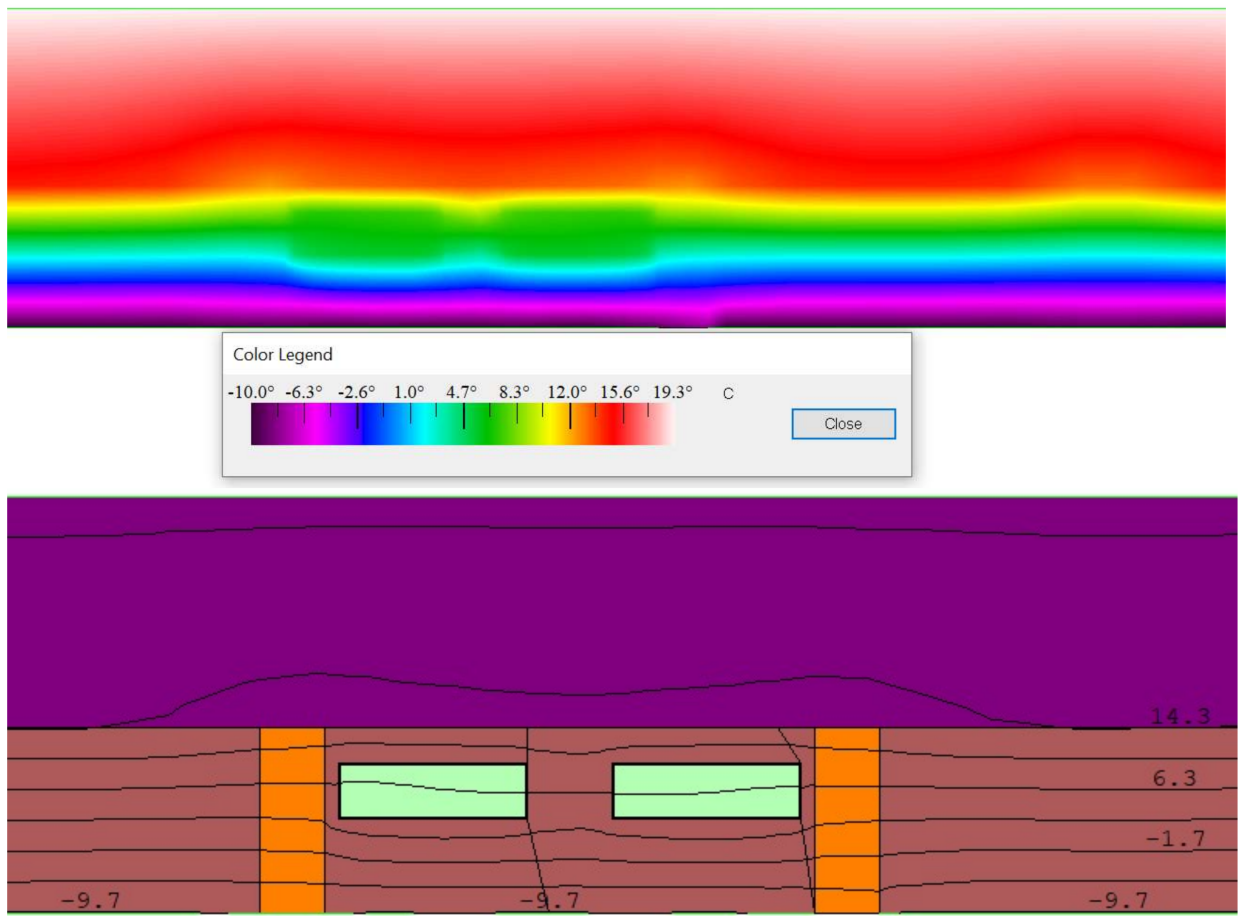

Figure 7. Impact of plastic pipe integration.

The overall heat flow through before mentioned construction is $16.8750 \mathrm{~W}$.

The presented cases reflect the retrofitting solutions of existing external building envelope. In general case application of extra thermal insulation five times reduced heat transfer coefficient of external wall to facilitate the construction process of a new building the wooden frame structures are considered in the scope of this research. Such structures allow precise control of materials and high assembly quality at factory during production. The additional advantage is the reduced number of on-site workers which is very essential for construction of unclassified buildings, where extra safety and accessibility restrictions are in place. Simplified wall solution for temporary building construction could replace tents, thus providing better energy efficiency of the enclosure. Additional simulation was carried out in COMSOL Multiphysics software to evaluate the effect of outdoor air circulations. The results of the simulation are shown in Figure 8.

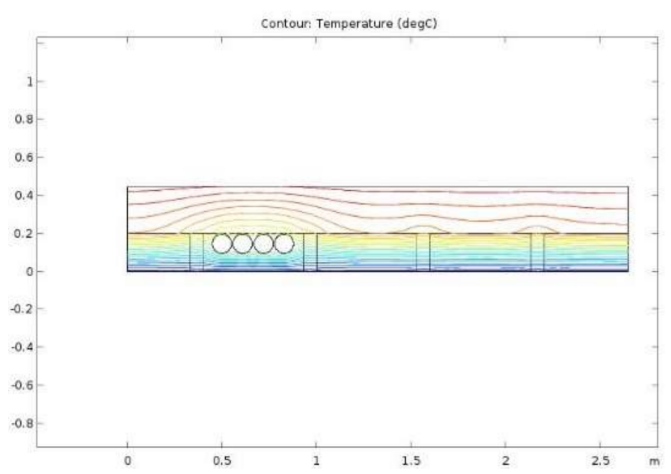

(a)

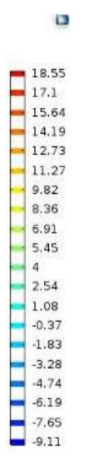

Figure 8. Isotherm distribution in COMSOL Multiphysics. (a) circulation air temperature $+5{ }^{\circ} \mathrm{C}$. (b) circulation air temperature $+0^{\circ} \mathrm{C}$.

Data obtained from COMSOL Multiphysics corelates with THERM software, which is more friendly for engineers and energy auditors. Thus, THERM is used in further calculations. 
Table 4 presents impact of air temperature in duct on heat losses calculated using THERM software.

Table 4. Effect of circulating air temperature on heat losses.

\begin{tabular}{|c|c|c|c|}
\hline $\begin{array}{l}\text { Circulating Air } \\
\text { Temperature }\end{array}$ & Isotherms & $\begin{array}{l}\text { Heat Flux, } \\
\text { W/m }\end{array}$ & $\begin{array}{l}\text { U-Value, } \\
\text { W/m } / \mathrm{m}^{2} \mathrm{~K}\end{array}$ \\
\hline$-10^{\circ} \mathrm{C}$ & & 27.662 & 0.346 \\
\hline $0^{\circ} \mathrm{C}$ & & 22.666 & 0.2836 \\
\hline$+5^{\circ} \mathrm{C}$ & $\infty$ & 20.167 & 0.2525 \\
\hline$+20^{\circ} \mathrm{C}$ & $\infty$ & 12.673 & 0.1586 \\
\hline
\end{tabular}

\subsection{Fire Resistance of Aramid Panels}

Based on the measurements made in special laboratory located at Forest and Wood Products Research and Development Institute in accordance with EN 13501-1, it was found that the ballistic panels are not flammable and do not form an overall flare (Figure 9) and Figure 10 shows example of fire testing.

The performed test had shown that the aramid panel has a potential combustion class A2/B, a smoke intensity level S2 and a burning droplets/particle class d0 [37].

It was observed that it is not possible to ignite the panels within thirty seconds. The amount of smoke emitted during combustion is not high. Given that the ballistic panel is a polymer, it is necessary to verify the toxicity of the smoke. Observations during the test indicate that the samples do not ignite when flame is applied to the surface. No combustible particles were observed during the test. Average combustion heat of analyzed samples was $5.5929 \mathrm{MJ} / \mathrm{kg}$. It should be mentioned that one of the samples has significantly lower combustion heat value-5.0796 MJ $/ \mathrm{kg}$. The result summary is shown in Figure 11.

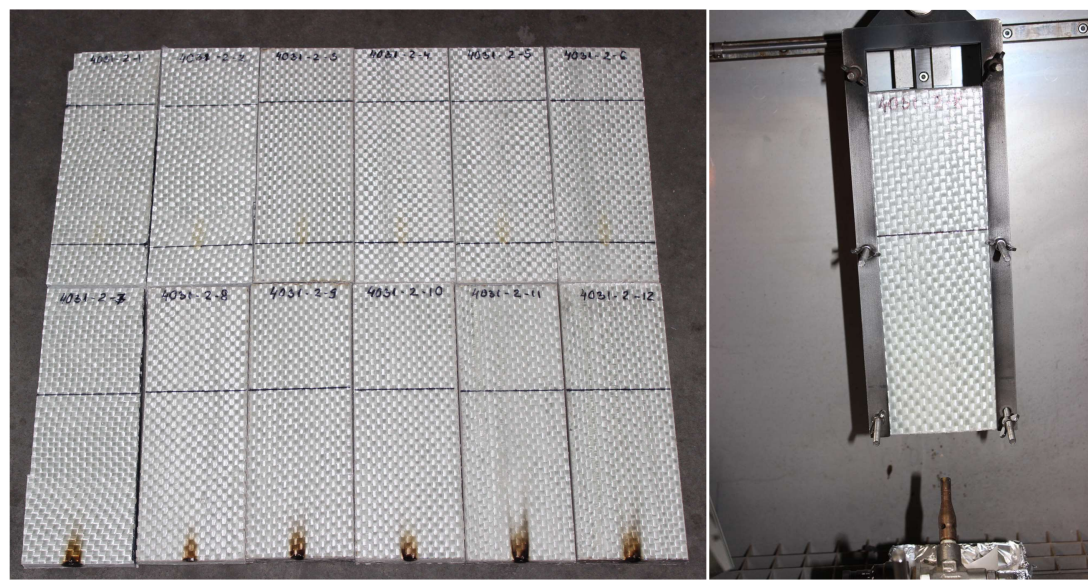

Figure 9. Influence of flame on ignition of ballistic panels. 


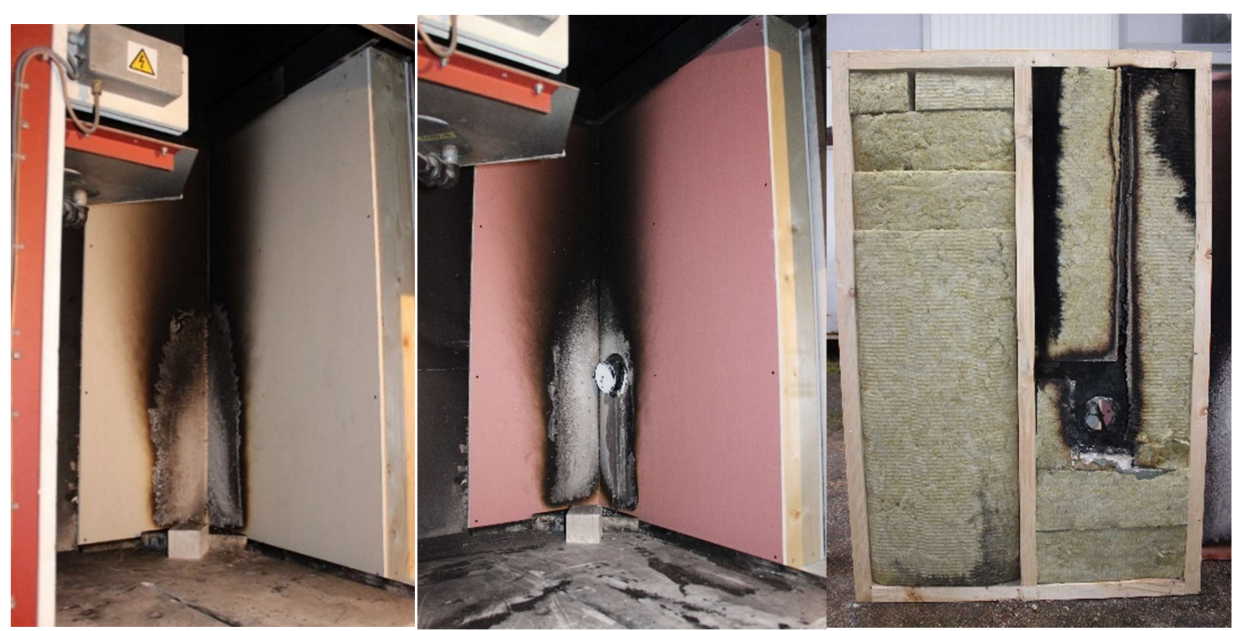

Figure 10. Example of fire testing of whole wall assembly.
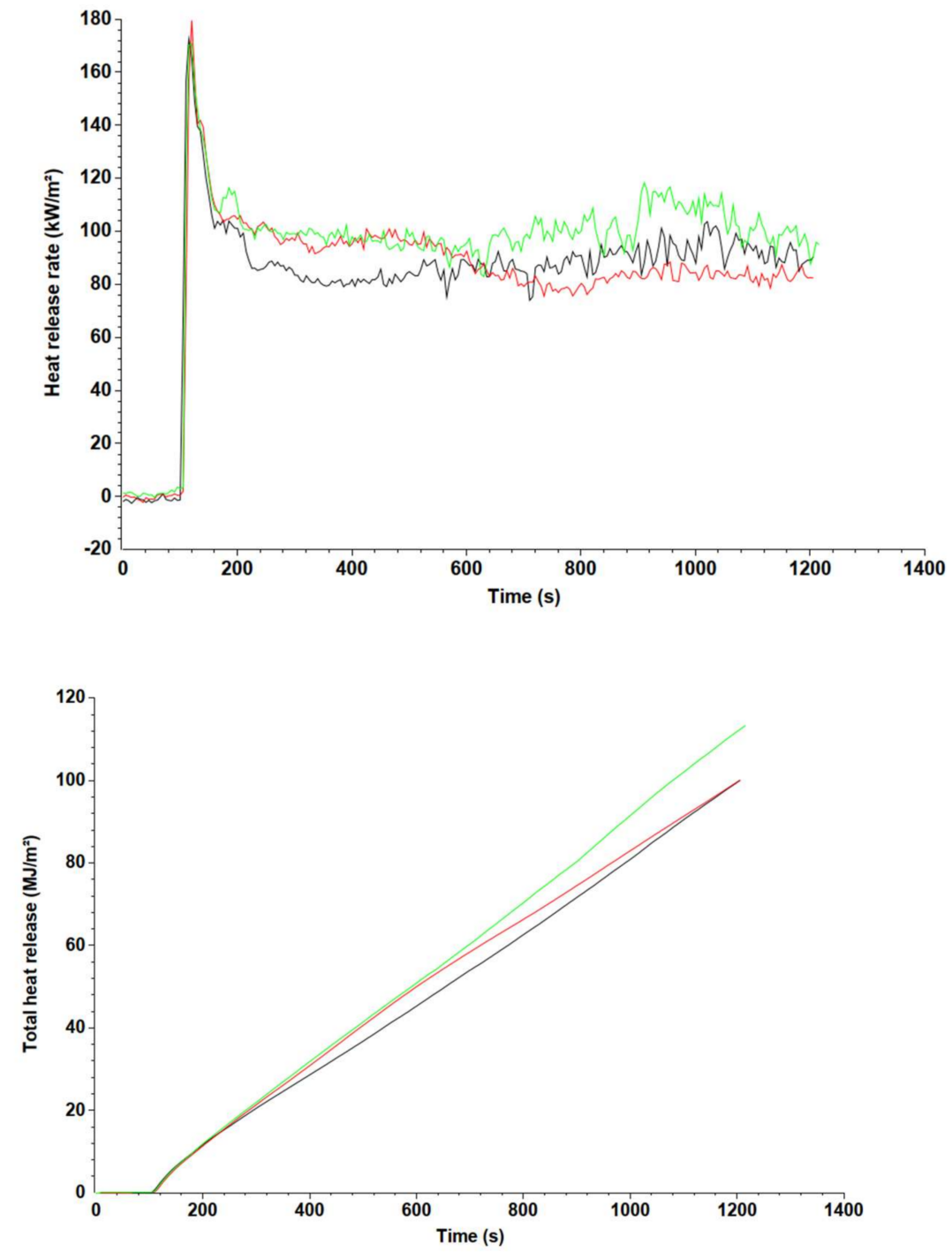

Figure 11. Amount of heat released during combustion of aramid panel (red-specimen 1; greenspecimen 2; blue-specimen 3).

The results of these tests are used by specifiers and contractors to determine the best fire rated insulation available for their needs. 
The fire resistance test for wooden frame structure with an integrated duct and fireresistant gypsum board finish showed that it complies with B-s2,d0 requirements, while the monolith wooden frame structure (without integrated elements) complies with Bs1,d0 classification.

The interpretation of the results in accordance with EN 13501-1 requirements is outlined in Table 5.

Table 5. Materials' fire classification according to EN 13501-1.

\begin{tabular}{|c|c|c|c|c|}
\hline \multirow[b]{2}{*}{$\begin{array}{l}\text { Building Inspection } \\
\text { Appointment }\end{array}$} & \multirow[b]{2}{*}{$\begin{array}{l}\text { Definition according } \\
\text { to DIN } 4102\end{array}$} & \multicolumn{3}{|c|}{ European Classification according to DIN EN 13501-1 } \\
\hline & & $\begin{array}{c}\text { Energetic } \\
\text { Contribution to Fire }\end{array}$ & Production of Smoke & Behavior of Droplets \\
\hline \multirow{2}{*}{ Non-flammable } & A1 & A1 & & \\
\hline & A2 & A2 & s1 & $\mathrm{d} 0$ \\
\hline \multirow{6}{*}{ Flame-retardant } & \multirow{6}{*}{ B1 } & $\mathrm{B}, \mathrm{C}$ & S1 & d0 \\
\hline & & $\mathrm{A} 2, \mathrm{~B}, \mathrm{C}$ & S2 & d0 \\
\hline & & $\mathrm{A} 2, \mathrm{~B}, \mathrm{C}$ & S3 & d0 \\
\hline & & $\mathrm{A} 2, \mathrm{~B}, \mathrm{C}$ & S1 & $\mathrm{d} 1$ \\
\hline & & $\mathrm{A} 2, \mathrm{~B}, \mathrm{C}$ & S1 & d2 \\
\hline & & $\mathrm{A} 2, \mathrm{~B}, \mathrm{C}$ & s3 & $\mathrm{d} 2$ \\
\hline \multirow{8}{*}{$\begin{array}{l}\text { Normal flammable } \\
\text { materials }\end{array}$} & \multirow{8}{*}{ B2 } & & s1 & $\mathrm{d} 0$ \\
\hline & & $\mathrm{D}$ & s2 & d0 \\
\hline & & & s3 & d0 \\
\hline & & $\mathrm{E}$ & & \\
\hline & & & s1 & $\mathrm{d} 2$ \\
\hline & & $\mathrm{D}$ & s2 & $\mathrm{d} 2$ \\
\hline & & & s3 & $\mathrm{d} 2$ \\
\hline & & E & & $\mathrm{d} 2$ \\
\hline No performance noted & B3 & F & & \\
\hline
\end{tabular}

\section{Discussion}

Embedded air ducts do not significantly reduce thermal performance of modular wooded frame structure. In the case when air at temperature below $\left(-10^{\circ}\right)$ circulates a significant increase in heat flow occurs, as lower heat transfer coefficient is observed.

The fire resistance of proposed construction has a similar properties as typical wooded frame constructions with drywall finishing.

As it was mentioned before, the weakest point of integrated ventilation ducts is the risk of bullet penetration into the ballistic panel and duct intersection. Selection of extra ballistic protection strongly depends on the angle and distance of shooting. The possible shooting positions, angle projections, and the effect on the selection of extra ballistic panel dimensions are shown in Figure 12.

The figure below shows the impact of a single shot on the fragment of the ballistic panel and the incurred damage on the panel's integrity. The 'sector' reflects the horizontal penetration depth ( $x$ axis), the 'elevation' reflects the vertical penetration depth ( $y$ axis).

Wooded frame construction with embedded duct and protected with aramid bullet proof panels allows to insure fast temporary building erection for different purposes including military training, refuses cams, and other structures in military conflict zones. 


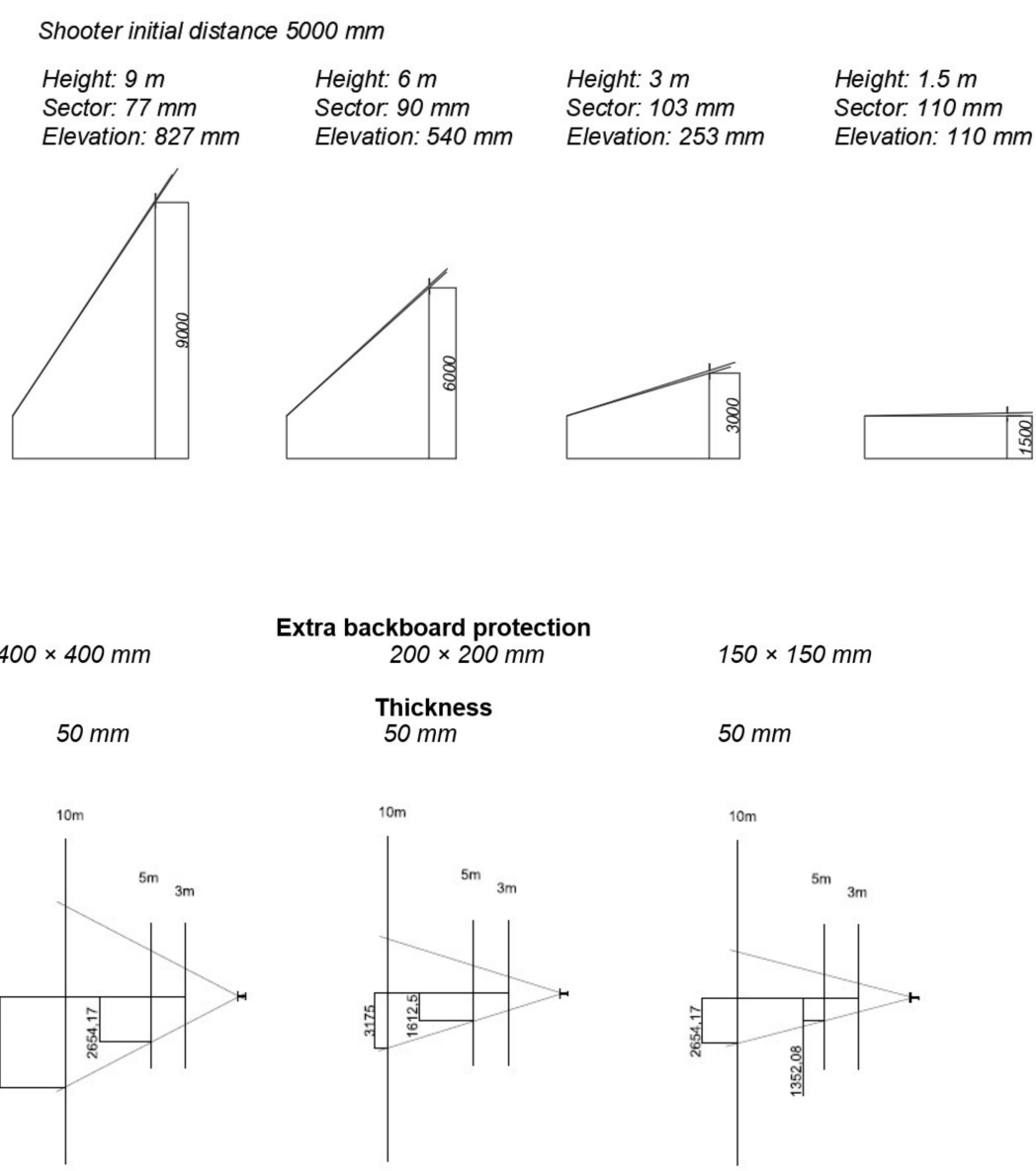

Figure 12. The possible shooting positions, angle projections.

\section{Conclusions}

Bullet proof wooden frame constructions can ensure both human protection in case of accidental shooting or attack, as well as ensure the energy efficiency of the whole building and fulfill fire safety requirements.

Made simulation has shown that embedded air duct does not have any negative impact on wall heat transfer coefficient. However, temperature of circulation air should not be lower than $+20{ }^{\circ} \mathrm{C}$. Heat transfer coefficient drops till $0.346 \mathrm{~W} /\left(\mathrm{m}^{2} \cdot \mathrm{K}\right)$ in case than air temperature drops till $-5^{\circ} \mathrm{C}$. In means such solution can be used in combination with mechanical ventilation equipped with exhaust air heat recovery. In other cases, it could be used as local outdoor air supply vents with length $0.5 \mathrm{~m}$ or shorter.

The fire resistance test for wooden frame structure with an integrated duct and showed that it complies with B-s2,d0 requirements, while the monolith wooden frame structure (without integrated ventilation elements) complies with B-s1,d0 classification.

Bullet proof panel could be place only on one side which significantly reduces construction costs while slightly compromises ballistic safety. Extra aramid backboard reduces this risk. The room layout should consider possible accidents and prevent working desks placement close to air vents. Safe place to install such local vents under the ceiling.

Light wooden frame construction with ballasting protection can be recommended to use in temporary military or other campuses thus insuring energy efficiency and human safety in case of accidental shooting.

\section{Patents}

Latvian patent application P-19-81. Ballistic durable wooden frame external wall panel with fresh air supply cable. 


\begin{abstract}
Author Contributions: Conceptualization, A.B. and A.G.; methodology, A.G.; software, V.J.; validation, A.G. and V.J.; formal analysis, A.G.; investigation, A.G.; resources, V.J.; data curation, E.B.; writing—original draft preparation, A.B.; writing—review and editing, V.J.; visualization, A.P.; supervision, A.B.; project administration, A.B.; funding acquisition, A.B. All authors have read and agreed to the published version of the manuscript.
\end{abstract}

Funding: This work was supported by the European Social Fund within the Project No 8.2.2.0/20/I/008 «Strengthening of PhD students and academic personnel of Riga Technical University and BA School of Business and Finance in the strategic fields of specialization» of the Specific Objective 8.2.2 «To Strengthen Academic Staff of Higher Education Institutions in Strategic Specialization Areas» of the Operational Programme «Growth and Employment».

Institutional Review Board Statement: The study did not involve humans or animals.

Informed Consent Statement: Not applicable.

Conflicts of Interest: The authors declare no conflict of interest.

\title{
References
}

1. Afonicevs, V.; Strauts, U.; Bogdanovs, N.; Lesinskis, A. Evaporative cooling technology efficiency compared to traditional cooling system-Case study. Eng. Rural Dev. 2020. [CrossRef]

2. Borodinecs, A.; Lebedeva, K.; Prozuments, A.; Brahmanis, A.; Grekis, A.; Zajecs, D.; Zekunde, A.; Vatin, N. Feasibility of reducing electricity consumption of air conditioning equipment by condenser direct evaporative cooling technology. Example of case study in Dubai. Atmosphere 2021, 12, 1205. [CrossRef]

3. Zajacs, A.; Borodinecs, A.; Vatin, N. Environmental impact of district heating system retrofitting. Atmosphere 2021, 12, 1110. [CrossRef]

4. Zajacs, A.; Borodinecs, A.; Bogdanovičs, R. Assessment of the efficiency and reliability of the district heating systems within different development scenarios. In Sustainability in Energy and Buildings. Smart Innovation, Systems and Technologies; Littlewood, J., Howlett, R., Capozzoli, A., Jain, L., Eds.; Springer: Singapore, 2020; Volume 163. [CrossRef]

5. Guo, X.; Ouyang, Q.; Sun, Y.; Weng, G.J. Ballistic performance of nanostructured metals toughened by elliptical coarse-grained inclusions: A finite element study with failure analysis. Materials 2018, 11, 977. [CrossRef] [PubMed]

6. Ziółkowski, G.; Pach, J.; Pyka, D.; Kurzynowski, T.; Jamroziak, K. X-ray computed tomography for the development of ballistic composite. Materials 2020, 13, 5566. [CrossRef] [PubMed]

7. Yang, Y.; Zhang, X.; Chen, X.; Min, S. Numerical study on the effect of Z-warps on the ballistic responses of para-aramid 3d angle-interlock fabrics. Materials 2021, 14, 479. [CrossRef] [PubMed]

8. Haro, E.E.; Szpunar, J.A.; Odeshi, A.G. Dynamic and ballistic impact behavior of biocomposite armors made of HDPE reinforced with chonta palm wood (Bactris gasipaes) microparticles. Def. Technol. 2018, 14, 238-249. [CrossRef]

9. Bhatnagar, A. Standards and specifications for lightweight ballistic materials. In Lightweight Ballistic Composites: Military and Law-Enforcement Applications; Woodhead Publishing: Cambridge, UK, 2006. [CrossRef]

10. Sanborn, K.P. Exploring Cross-Laminated Timber Use for Temporary Military Structures: Ballistic Considerations. Master's Thesis, Georgia Institute of Technology, Atlanta, GA, USA, 30 March 2018.

11. Sanborn, K.; Gentry, T.R.; Koch, Z.; Valkenburg, A.; Conley, C.; Stewart, L.K. Ballistic performance of Cross-laminated Timber (CLT). Int. J. Impact Eng. 2019, 128, 11-23. [CrossRef]

12. Koene, L.; Broekhuis, F.R. Bullet penetration into wooden targets. In Proceedings of the 30th International Symposium on Ballistics, BALLISTICS 2017, Long Beach, CA, USA, 11-15 September 2017. [CrossRef]

13. Jover, N.; Shafiq, B.; Vaidya, U. Ballistic impact analysis of balsa core sandwich composites. Compos. Part B Eng. 2014, 67, 160-169. [CrossRef]

14. Kalamees, T.; Vinha, J. Hygrothermal calculations and laboratory tests on timber-framed wall structures. Build. Environ. 2003, 38, 689-697. [CrossRef]

15. Gilstrap, J.M.; Dolan, C.W. Out-of-plane bending of frp-reinforced masonry walls. Compos. Sci. Technol. 1998, 58, 1277-1284. [CrossRef]

16. Pirvu, C.; Ionescu, T.F.; Deleanu, L.; Badea, S. Simplified simulation of impact bullet-stratified pack for restraining ballistic tests. MATEC Web Conf. 2017, 112, 6. [CrossRef]

17. Haro Albuja, E.; Szpunar, J.A.; Odeshi, A.G. Ballistic impact response of laminated hybrid materials made of 5086-H32 aluminum alloy, epoxy and Kevlar ${ }^{\circledR}$ fabrics impregnated with shear thickening fluid. Compos. Part A Appl. Sci. Manuf. 2016, 87, 54-65. [CrossRef]

18. Zhou, A.; Qiu, Q.; Chow, C.L.; Lau, D. Interfacial performance of aramid, basalt and carbon fiber reinforced polymer bonded concrete exposed to high temperature. Compos. Part A Appl. Sci. Manuf. 2020, 131, 105802. [CrossRef]

19. Chen, X.; Wang, W.; Li, S.; Jiao, C. Fire safety improvement of para-aramid fiber in thermoplastic polyurethane elastomer. J. Hazard. Mater. 2017, 324, 789-796. [CrossRef] 
20. Zhang, L.; Chen, Z.; Dong, H.; Fu, S.; Ma, L.; Yang, X. Wood plastic composites based wood wall's structure and thermal insulation performance. J. Bioresour. Bioprod. 2021, 6, 65-74. [CrossRef]

21. Zhivov, A.M.; Case, M.; Liesen, R.; Kimman, J.; Broers, W. Energy master planning towards net-zero energy communities/campuses. ASHRAE Trans. 2014, 120, 114-129.

22. Charani Shandiz, S.; Rismanchi, B.; Foliente, G. Energy master planning for net-zero emission communities: State of the art and research challenges. Renew. Sustain. Energy Rev. 2020, 137, 110600. [CrossRef]

23. Borodinecs, A.; Geikins, A.; Prozuments, A. Energy consumption and retrofitting potential of Latvian unclassified buildings. In Sustainability in Energy and Buildings. Smart Innovation, Systems and Technologies; Littlewood, J., Howlett, R., Capozzoli, A., Jain, L., Eds.; Springer: Singapore, 2020; Volume 163, pp. 319-326.

24. Borodinecs, A.; Prozuments, A.; Zemitis, J.; Zajecs, D.; Bebre, G. Hydrothermal performance of the external wooded frame wall structure reinforced with ballistic panels. E3S Web Conf. 2020, 172, 07005. [CrossRef]

25. Wei, W.; Ramalho, O.; Mandin, C. Indoor air quality requirements in green building certifications. Build. Environ. 2015, 92, 10-19. [CrossRef]

26. Kamali, M.; Hewage, K. Life cycle performance of modular buildings: A critical review. Renew. Sustain. Energy Rev. 2016, 62, 1171-1183. [CrossRef]

27. Blismas, N.; Pasquire, C.; Gibb, A. Benefit evaluation for off-site production in construction. Constr. Manag. Econ. 2006, 24, 121-130. [CrossRef]

28. Zemitis, J.; Borodinecs, A.; Bogdanovics, R.; Geikins, A. Case Study of Thermal Comfort in a Temporary Shelter. J. Sustain. Arch. Civ. Eng. 2021, 29, 139-149. [CrossRef]

29. Bui, T.T.; Limam, A.; Desevedavy, G.; Damichey, D. Highly environmental-efficient modular houses considering construction and deconstruction aspects. In CIGOS 2021, Emerging Technologies and Applications for Green Infrastructure. Lecture Notes in Civil Engineering; Ha-Minh, C., Tang, A.M., Bui, T.Q., Vu, X.H., Huynh, D.V.K., Eds.; Springer: Singapore, 2022; Volume 203, pp. 657-665. [CrossRef]

30. EN ISO 10211-1. Thermal Bridges in Building Construction-Heat Flows and Surface Temperatures-Detailed Calculations; CEN: Brussels, Belgium, 2007.

31. American Society for Testing and Materials. ASTM C 518-17: Standard Test Method for Steady-State Thermal Transmission Properties by Means of the Heat Flow Meter Apparatus; ASTM: West Conshohocken, PA, USA, 2017.

32. ISO 8301: ISO 8301:1991. Thermal Insulation: Determination of Steady-State Thermal Resistance and Related Properties. Heat Flow Meter Apparatus; International Organization for Standardization: Geneva, Switzerland, 1991.

33. DIN: DIN EN 12667. Thermal Performance of Building Materials and Products-Determination of Thermal Resistance by Means of Guarded Hot Plate and Heat Flow Meter Methods_-Products of High and Medium Thermal Resistance; CEN: Brussels, Belgium, 2001.

34. DIN: DIN EN 13163. Thermal Insulation Products for Buildings_Factory Made Expanded Polystyrene (EPS) Products—Specification; includes Amendment: 2016; CEN: Brussels, Belgium, 2017.

35. JSA: JIS A 1412. Test Method for Thermal Resistance and Related Properties of Thermal Insulations; CEN: Brussels, Belgium, 2016.

36. Andreeva, T. Review of Linear Thermal Bridges in High-Rise Building. Bachelor's Thesis, Oulu University of Applied Sciences, Oulu, Finland, 2013.

37. EN: EN 13501-1:2005. Fire Classification of Construction Products and Building Elements_Part 1: Classification Using Data from Reaction to Fire Tests; CEN: Brussels, Belgium, 2009. 